\title{
Inheritance of Rugose Leaf in Caladium and Genetic Relationships with Leaf Shape, Main Vein Color, and Leaf Spotting
}

\author{
Zhe Cao \\ Department of Environmental Horticulture, Gulf Coast Research and Education Center, University of \\ Florida/IFAS, 14625 County Road 672, Wimauma, FL 33598 \\ Shunzhao Sui \\ College of Horticulture and Landscape, Southwest University, Chongqing, 400715, P.R. China \\ Qian Yang and Zhanao Deng ${ }^{1}$ \\ Department of Environmental Horticulture, Gulf Coast Research and Education Center, University of \\ Florida/IFAS, 14625 County Road 672, Wimauma, FL 33598
}

\begin{abstract}
AdDitional INDEX words. Araceae, Caladium $\times$ hortulanum, foliar characteristics, genetic linkage, genetic recombination, ornamental aroid

Abstract. A number of caladium cultivars (Caladium $\times$ hortulanum), including Miss Muffet and Gingerland, produce rugose leaves. The rugosity on these leaves is an intriguing characteristic, often resulting in an increased ornamental value. This study was conducted to understand the mode of inheritance of this trait and to determine its genetic relationship with other foliar characteristics including leaf shape, main vein color, and leaf spotting in caladiums. Sixteen caladium cultivars/breeding lines were crossed and 20 populations were produced; progeny of these populations were phenotyped for rugose leaf as well as leaf shape, main vein color, and leaf spotting. Results showed that a single locus with two alleles controlled the presence or absence of rugose leaves in these populations. The locus was designated as $R L F$, with the dominant $R L F$ allele for rugose leaves and the recessive allele rlf for nonrugose (flat) leaves. Rugose cultivars Miss Muffet and Gingerland and breeding line UF-317 possessed the heterozygous genotype $R L F r l f$. Rugose leaf was inherited independently from leaf shape, but linked with the green main vein allele $\left(V^{\mathrm{g}}\right)$ at the $V$ locus and the leaf spotting allele $(S)$ at the $S$ locus. Three-point analysis of the segregation of the three linked traits in reciprocal crosses between 'Miss Muffet' and nonrugose 'Candidum' indicated a genetic linkage map with the gene order of $S$ locus locating between the $V$ and the $R L F$ loci. The information obtained from this study will be useful for developing breeding strategies for producing new caladium cultivars with or without rugose leaves, and can facilitate the understanding of the mode of inheritance for rugose leaves in other aroids and other plants.
\end{abstract}

Cultivated caladium is an ornamental aroid produced for container or hanging basket plants or grown in landscapes for their variably shaped, colorful foliage. The ornamental value of caladium plants, to a great extent, depends on their leaf characteristics (Deng and Harbaugh, 2009). Improving leaf characteristics or creating novel combinations has been a main objective in caladium breeding and new cultivar development (Wilfret, 1993). The main breeding approach used in caladium has been hybridizations between elite cultivars or breeding lines. In recent years, significant efforts have been made to understand the mode of inheritance of several important caladium foliar traits, including leaf shape, main vein color, leaf spotting, and leaf blotching (Deng and Harbaugh, 2006, 2009; Deng et al., 2008; Gager, 1991; Wilfret, 1983). It is known now that caladium leaf shape is controlled by a single locus $(F)$ with two alleles $(F$ and $f$ ). Genotypes $F F, F f$, and $f f$ confer fancy, lance, and strap (ribbon like) leaves, respectively.

Received for publication 22 June 2016. Accepted for publication 18 July 2016. This project was funded in part by USDA-NIFA hatch projects FLA-GCR005065 and FLA-GCC-005605.

We thank Joyce Jones, Gail Bowman, and Weining Wang for their technical assistance and Kenneth Quesenberry, Samuel Hutton, Seonghee Lee, Ryan Warner, and Manjul Dutt for their critical review of the manuscript and valuable suggestions.

${ }^{1}$ Corresponding author. E-mail: zdeng@ufl.edu.
The main vein color of caladium is controlled by the locus $V$, with three alleles, $V^{\mathrm{r}}, V^{\mathrm{w}}$, and $V^{\mathrm{g}}$, for red, white, and green main veins, respectively (Deng and Harbaugh, 2006). The presence or absence of leaf spots is controlled by a single locus $S$, with the $S$ allele for spotting and the $s$ allele for nonspotting (Deng et al., 2008). Similarly, leaf blotching is determined by a single locus $(B)$ with a dominant allele $B$ for blotching and a recessive allele $b$ for nonblotching (Deng and Harbaugh, 2009). The knowledge gained over the last 25 years on trait inheritance has been valuable for selecting breeding parents and parental combinations and planning breeding populations in caladium.

A number of caladium cultivars produce rugose leaves. These leaves exhibit uneven leaf blades, with large irregularly sunken or elevated areas on both sides. The expression of rugose leaf is genotype dependent and stable under different growing conditions or cultural practices and in different growing stages (personal observation). The expression of rugose leaf results in intriguing leaves with ruffled margins and often increased ornamental value. This characteristic has been also used for cultivar identification. Thus, rugose leaf is an important foliar trait in caladium. A number of major cultivars exhibit rugose leaves, including Miss Muffet and Gingerland, both of which have been popular for decades (Bell et al., 1998; Deng et al., 2005).

Information on the inheritance of rugose leaf is not available in caladium or other aroids, but several modes of inheritance 
have been reported for rugose leaf in other plants. For example, rugose leaf in upland cotton (Gossypium hirsutum) was controlled by a single nuclear locus, with a dominant allele for rugose leaf and a recessive allele for nonrugose leaf (flat leaves) (Turcotte and Feaster, 1965). A pair of recessive alleles was found to determine the expression of rugose leaf in soybean (Glycine max) and eggplant (Solanum melongena) (Csillery, 1983; Wilcox and Abney, 1991). Chow (1982) reported that the rugose leaf in Desmodium was controlled by three loci. Stephens et al. (1991) reported that a cytoplasmic gene or genes caused the expression of rugose leaf in some soybean.

The objectives of this study were to 1) understand the mode of inheritance of rugose leaf in caladiums, 2) determine the genotypes of these caladium cultivars and breeding lines for rugose leaf, and 3) determine the genetic relationships of rugose leaf with leaf shape, main vein color, and leaf spotting.

\section{Materials and Methods}

Plant material. Twelve commercial caladium cultivars and four breeding lines were used as parents in 20 crosses. Three parents, 'Gingerland', 'Miss Muffet', and breeding line UF-317, displayed rugose leaves (Fig. 1). Thirteen parents, including 'Aaron', 'Candidum', 'Carolyn Whorton', 'Fairytale Princess', 'Florida Fantasy', 'Florida Moonlight', 'Florida Sweetheart', 'Red Flash', 'Red Hot', 'Tapestry', and breeding lines UF-52, UF-53, and UF4607 exhibited nonrugose, flat leaves. The phenotypes and inferred genotypes of these parents for rugose leaf as well as leaf shape, main vein color, and spotting are listed in Table 1.

Flower INDUCTION AND CROSSING. Jumbo-sized tubers (6.4 to $8.9 \mathrm{~cm}$ diameter) were treated with $600 \mathrm{mg} \cdot \mathrm{L}^{-1}$ gibberellic acid $\left[\mathrm{GA}_{3}\right.$ (ProGibb; Valent BioSciences, Libertyville, IL)] in May 2012 as described by Harbaugh and Wilfret (1979). Four to six treated tubers per parent were planted in plastic containers (20 $\mathrm{cm}$ diameter) filled with a soilless potting mix (Fafard 3B; Conrad Fafard, Agawam, MA). Plants were fertilized with $5 \mathrm{~g}$ of $18 \mathrm{~N}-2.6 \mathrm{P}-10 \mathrm{~K}$ control-released fertilizer (Osmocote $^{\circledR}$; Scotts, Marysville, $\mathrm{OH}$ ) per plant and handwatered daily. All parental plants were grown in a greenhouse with fans and cooling pads, and the temperature in the greenhouse was maintained between 23 and $30^{\circ} \mathrm{C}$. Controlled pollination was conducted from early July to mid-Sept. 2012,
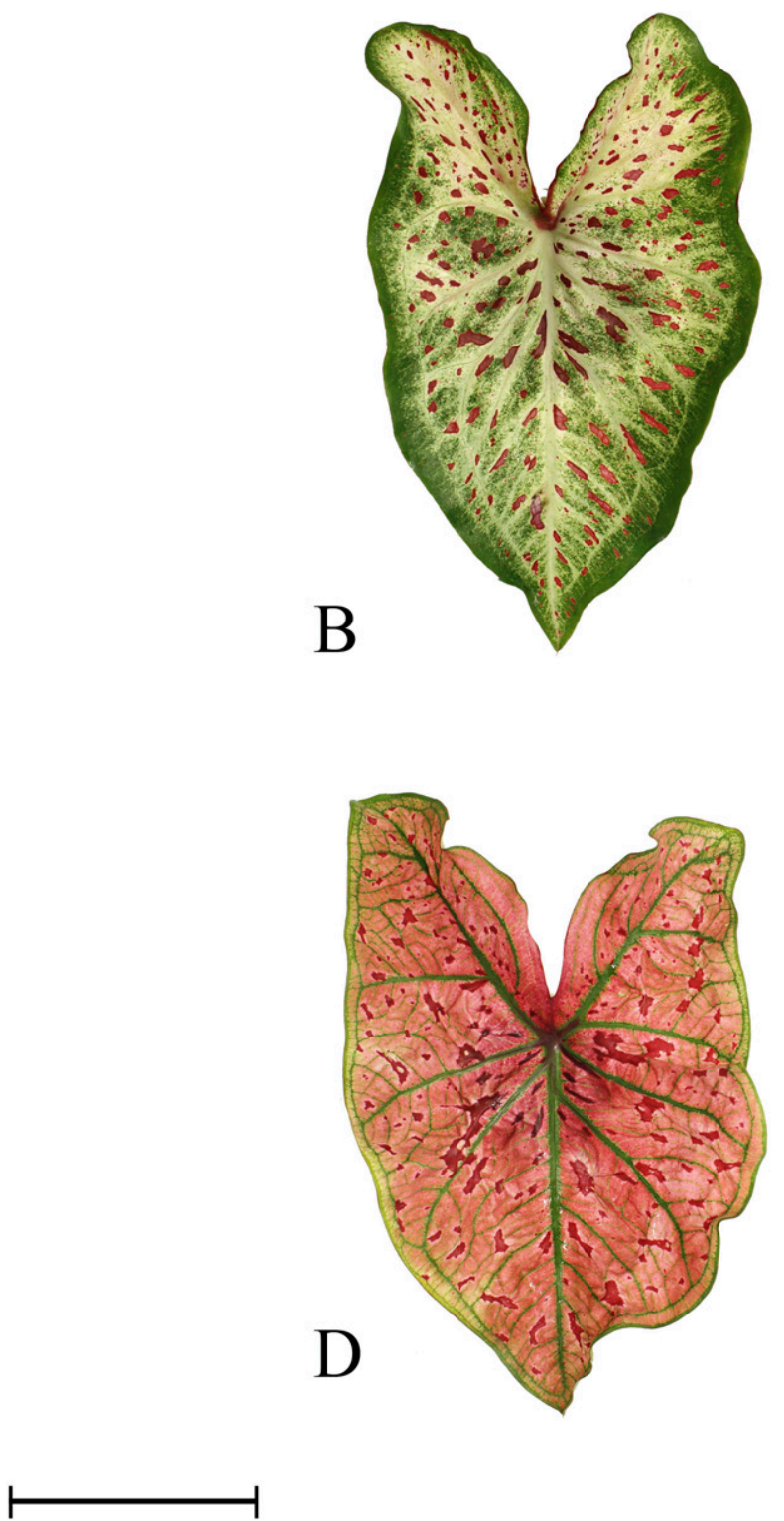

Fig. 1. Typical leaves of three caladium cultivars Miss Muffet [A (fancy, rugose, spotted, and white veined)], Gingerland [B (lance, rugose, spotted, and white veined)], and Red Flash [C (fancy, nonrugose, spotted, and red veined)], and breeding line UF-317 [D (fancy, rugose, spotted, and green veined)]; scale bar $=5 \mathrm{~cm}$.

as described by Deng and Harbaugh (2006). Pollen was collected from the staminate flowers using cotton swabs and applied onto the stigmatic surface of receptive pistillate flowers 1-2 d before anthesis. Mature fruit were harvested 30 to $35 \mathrm{~d}$ after pollination (from mid-July to late Oct. 2012). Seeds were extracted and dried on paper towels.

Progeny growing. Dried seeds were sown in 20-row germination trays filled with a commercial soilless substrate (Fafard Super Fine Germination Mix, Conrad Fafard). Seeds were germinated in a growth room with a constant temperature of $25{ }^{\circ} \mathrm{C}$ and continuous light (cool fluorescent lights, 30 $\mu \mathrm{mol} \cdot \mathrm{m}^{-2} \cdot \mathrm{s}^{-1}$ ). One month later, seedlings were transplanted to 128-cell planter trays filled with a potting mix (Fafard 3B) and grown in a greenhouse. Young plants were fertilized twice per week with a commercial water-soluble fertilizer with a formula containing (wt/wt) 1.1\% ammonia-N, 11.8\% nitrate-N, 2.1\% urea-N, 2.2\% P, and 12.5\% K (Peters ${ }^{\circledR}$ Excel; Everris NA, 
Table 1. Phenotype and genotype of 12 commercial caladium cultivars and four breeding lines used as parents in crosses made in this study.

\begin{tabular}{|c|c|c|c|c|c|c|c|c|}
\hline \multirow[b]{2}{*}{ Cultivar or breeding line } & \multicolumn{2}{|c|}{ Leaf spotting } & \multicolumn{2}{|c|}{ Leaf shape } & \multicolumn{2}{|c|}{ Main vein color } & \multicolumn{2}{|c|}{ Rugose leaf } \\
\hline & Phenotype & Genotype ${ }^{z}$ & Phenotype & Genotype & Phenotype & Genotype & Phenotype & Genotype $^{y}$ \\
\hline Aaron & No & $s S$ & Fancy & $F F$ & White & $V^{\mathrm{w}} V^{\mathrm{w}}$ & No & rlfrlf \\
\hline Candidum & No & ss & Fancy & $F F$ & Green & $V^{\mathrm{g}} V^{\mathrm{g}}$ & No & rlfrlf \\
\hline Fairytale Princess & No & $s S$ & Lance & $F f$ & Red & $V^{\mathrm{r}} V^{\mathrm{g}}$ & No & rlfrlf \\
\hline Florida Fantasy & No & ss & Fancy & $F F$ & Red & $V^{\mathrm{r}} V^{\mathrm{g}}$ & No & Rlfrlf \\
\hline Florida Moonlight & No & ss & Fancy & $F F$ & White & $V^{\mathrm{w}} V^{\mathrm{g}}$ & No & rlfrlf \\
\hline Gingerland & Yes & Ss & Lance & $F f$ & White & $V^{\mathrm{w}} V^{\mathrm{g}}$ & Yes & RLFrlf \\
\hline Miss Muffet & Yes & Ss & Fancy & $F F$ & White & $V^{\mathrm{w}} V^{\mathrm{g}}$ & Yes & RLFrlf \\
\hline Red Flash & Yes & Ss & Fancy & $F F$ & Red & $V^{\mathrm{T}} V^{\mathrm{g}}$ & No & rlfrlf \\
\hline Red Hot & No & ss & Lance & $F f$ & Red & $V^{\mathrm{r}} V^{\mathrm{g}}$ & No & rlfrlf \\
\hline Tapestry & No & $s S$ & Fancy & $F F$ & Red & $V^{\mathrm{r}} V^{\mathrm{g}}$ & No & rlfrlf \\
\hline UF-52 & No & $s S$ & Fancy & $F F$ & White & $V^{\mathrm{w}} V^{\mathrm{g}}$ & No & rlfrlf \\
\hline
\end{tabular}

'Genotypes of 'Candidum', 'Carolyn Whorton', and 'Gingerland' for leaf shape, main vein color, and leaf spotting were reported previously (Deng et al., 2008), and they were confirmed in this study. Genotypes of 'Aaron', 'Florida Moonlight', 'Florida Sweetheart', and 'Red Flash' for leaf shape and vein color were determined by Deng and Harbaugh (2006), and their genotypes for leaf spotting were inferred in this study. Genotypes of five cultivars (Fairytale Princess, Florida Fantasy, Miss Muffet, Red Hot, and Tapestry) and three breeding lines (UF-52, UF-53, and UF-317) for leaf spotting, leaf shape, and vein color were inferred in this study. Symbols for caladium alleles are as follows: $S$ and $s$ for spotted and nonspotted leaves, respectively; $F$ and $f$ for fancy and strap leaf shapes, respectively; $V^{\mathrm{g}}, V^{\mathrm{w}}$, and $V^{\mathrm{r}}$ for green, white, and red main veins, respectively; and $R L F$ and $r l f$ for rugose and nonrugose leaves, respectively.

y'Inferred in this study.

Dublin, $\mathrm{OH})$. Young plants were transplanted from the planter trays to raised ground beds in Apr. and May 2013. The preparation of ground beds and growing of the caladium plants in the field were done as described by Deng et al. (2008). Each plant was fertilized with $7.5 \mathrm{~g}$ of $18 \mathrm{~N}-2.6 \mathrm{P}-10 \mathrm{~K}$ controlledrelease fertilizer during the growing season.

Phenotypic analysis. All progeny were individually examined for rugose leaf (rugose or nonrugose) as well as leaf shape (fancy or lance), main vein color (red, white, or green), and leaf spotting (present or absent) in June and Aug. 2014. Each progeny was examined at least four times during this period of time and by at least two persons each time.

Statistical analysis. Data analysis was conducted in three sequential steps: chi-square tests were conducted for goodness of fit of individual traits' segregation ratios to expected ratios, followed by contingency chi-square tests for the possibility of independence or linkage between traits, and when genetic linkage was evident, identification of proper recombinant progeny and calculation of recombination frequencies between linked loci. Chi-square tests for goodness of fit and contingency chi-square tests for independence were performed using the program at the website developed by Preacher (2001). Segregating populations used for estimating recombination frequencies fell into either pseudo $\mathrm{BC}_{1}$ or pseudo $\mathrm{F}_{2}$ populations. Pseudo $\mathrm{BC}_{1}$ populations resulted from crossing a heterozygous parent and a homozygous recessive parent in the traits of interest. In pseudo $\mathrm{BC}_{1}$ populations, the numbers of recombinant progeny were divided by the total numbers of progeny in the segregating populations to obtain recombination frequencies. Pseudo $\mathrm{F}_{2}$ populations were derived from crosses of two heterozygous parents in the traits of interest. In this type of populations, the numbers of double recessive progeny were divided by the total numbers of progeny to calculate the recombination frequencies between traits. Recombination frequencies were converted to genetic distances in centimorgans using the Kosambi's mapping function $\{\mathrm{m}=1 / 4 \ln [(1+2 r) /$ $(1-2 r)] \times 100\}$, where $\mathrm{m}$ is the genetic distance between loci in centimorgans, ln the natural logarithm, and $r$ the recombination fraction.

\section{Results}

INHERITANCE OF RUgose LEAF. Progeny from selfed 'Miss Muffet' segregated in a 3 (rugose): 1 (nonrugose) ratio [Table 2 (cross no. 1), $P=0.615]$. So, did the progeny of the crosses UF$317 \times$ 'Gingerland' and 'Miss Muffet' $\times$ 'Gingerland' [Table 2 (cross nos. 2 and 3), $P=0.244$ to 0.942$]$. This segregation ratio suggests that the rugose leaf phenotype is controlled by a single locus with two alleles, a dominant rugose leaf allele and a recessive nonrugose leaf allele. The segregation ratio also suggests that 'Miss Muffet', 'Gingerland', and breeding line UF-317 were heterozygous at this locus. Progeny of 'Gingerland' $\times$ 'Miss Muffet' [Table 2 (cross no. 4)], a reciprocal cross of cross no. 3, also segregated in a 3 (rugose):1 (nonrugose) ratio $(P=0.372)$, suggesting that maternal factors are not involved in the inheritance of rugose leaves.

When nonrugose parents, 'Red Flash' and 'Candidum', were crossed with 'Gingerland' or 'Miss Muffet', their progeny segregated in a $1: 1$ ratio [Table 2 (cross nos. 5 to $8), P=0.091$ to 0.493 ]. When nonrugose parents, 'Red Flash', 'Red Hot', 'Florida Fantasy', 'Tapestry', 'Carolyn Whorton', 'Florida Sweetheart', UF-4607, and 'Candidum' were crossed [Table 2 (cross no. 9 to 13)], their progeny all exhibited nonrugose leaves, suggesting these commercial cultivars or breeding lines are all homozygous recessive for the rugose leaf trait. 
Six other nonrugose cultivars or breeding lines (Aaron, Fairytale Princess, Florida Fantasy, Florida Moonlight, UF-52, and UF53) were also crossed with Miss Muffet, Gingerland, or UF-317 to validate the above model for the mode of inheritance of rugose leaves. Progeny of these crosses [(Table 2 (cross nos. 14 to 20)] all segregated in a 1 (rugose): 1 (nonrugose) ratio $(P=0.210$ to 0.746$)$.

In summary, the segregation ratios in the progeny of all 20 crosses indicated that the rugose leaf trait in 'Miss Muffet', 'Gingerland', and UF-317 is controlled by a single nuclear locus with a dominant allele for rugose leaves and a recessive allele for the nonrugose leaves. We propose to name the locus as $R L F$ (rugose leaf), with the dominant $R L F$ allele for rugose leaves and the recessive $r f$ allele for nonrugose leaves. 'Miss
Muffet', 'Gingerland', and UF-317 have a genotype of RLFrlf (Table 1). The 10 caladium cultivars and three breeding lines with nonrugose leaves are homozygous recessive with the genotype of rlfrlf (Table 1).

GENETIC RELATIONSHIP BETWEEN RUGOSE LEAF AND LEAF SHAPE. Previous studies showed that caladium leaf shape is controlled by a single locus with two codominant alleles ( $F$ and $f$ ), with the genotype $F F, F f$, and $f f$ determining the fancy, lance, and strap leaves, respectively (Deng and Harbaugh, 2006) and the lance-leaved 'Gingerland' carries the $F f$ genotype (Deng et al., 2008). On the basis of this model, it could be inferred that the fancy-leaved 'Miss Muffet' and UF-317 possess the FF genotype (Table 1).

Table 2. Segregation for rugose leaf in progeny of 20 caladium crosses.

\begin{tabular}{|c|c|c|c|c|c|}
\hline \multirow[b]{2}{*}{ Cross (cross no.) } & \multicolumn{2}{|c|}{ Caladium progeny (no.) } & \multirow[b]{2}{*}{ Expected ratio ${ }^{y}$} & \multirow[b]{2}{*}{$\chi^{2}$} & \multirow[b]{2}{*}{$P$} \\
\hline & $\overline{\text { Rugose }\left(R L F \_\right)^{\mathrm{z}}}$ & Nonrugose $(\text { rlfrlf })^{\mathrm{z}}$ & & & \\
\hline 'Miss Muffet' $(R L F r l f) \times$ self $(1)$ & 290 & 91 & $3: 1$ & 0.253 & 0.615 \\
\hline UF-317 $(R L F r l f) \times$ 'Gingerland' $(R L F r l f)(2)$ & 47 & 16 & $3: 1$ & 0.005 & 0.942 \\
\hline 'Gingerland' $(R L F r l f) \times$ 'Miss Muffet' $(R L F r l f)(4)$ & 160 & 61 & $3: 1$ & 0.798 & 0.372 \\
\hline 'Red Flash' $(r l f r l f) \times$ 'Gingerland' $($ RLFrlf $)(5)$ & 17 & 13 & $1: 1$ & 0.533 & 0.465 \\
\hline 'Gingerland' (RLFrlf $\times$ 'Red Flash' (rlfrlf) (6) & 50 & 43 & $1: 1$ & 0.527 & 0.468 \\
\hline 'Miss Muffet' $(R L F r l f) \times$ 'Candidum' $($ rlfrlf $)(8)$ & 345 & 302 & $1: 1$ & 2.858 & 0.091 \\
\hline 'Red Flash' (rlfrlf) $\times$ 'Florida Fantasy' (rlfrlf) (9) & 0 & 86 & $0: 1$ & & \\
\hline 'Red Flash' $($ rlfrlf $) \times$ UF-4607 (rlfrlf) $(10)$ & 0 & 101 & $0: 1$ & & \\
\hline 'Candidum' $($ rlfrlf $) \times \operatorname{self}(11)$ & 0 & 76 & $0: 1$ & & \\
\hline 'Tapestry' (rlfrlf) $\times$ 'Red Hot' $(r l f r l f)(12)$ & 0 & 64 & $0: 1$ & & \\
\hline 'Florida Sweetheart' $(r l f r l f) \times$ 'Carolyn Whorton' $($ rlfrlf $)(13)$ & 0 & 84 & $0: 1$ & & \\
\hline UF-317 $($ RLFrlf $) \times$ 'Florida Moonlight' $($ rlfrlf $)(18)$ & 67 & 58 & $1: 1$ & 0.648 & 0.421 \\
\hline UF-52 (rlfrlf) $\times$ UF-317 (RLFrlf) (19) & 44 & 33 & $1: 1$ & 1.571 & 0.210 \\
\hline UF-53 $($ rlfrlf $) \times$ 'Gingerland' $(R L F r l f)(20)$ & 8 & 6 & $1: 1$ & 0.286 & 0.593 \\
\hline
\end{tabular}

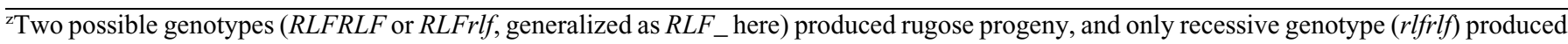
nonrugose (flat) progeny.

${ }^{\mathrm{y}}$ Segregation ratios expected for traits controlled by single dominant nuclear genes.

Table 3. Joint segregation of leaf shape (fancy and lance) and rugose leaf (rugose and nonrugose) in progeny of five caladium crosses.

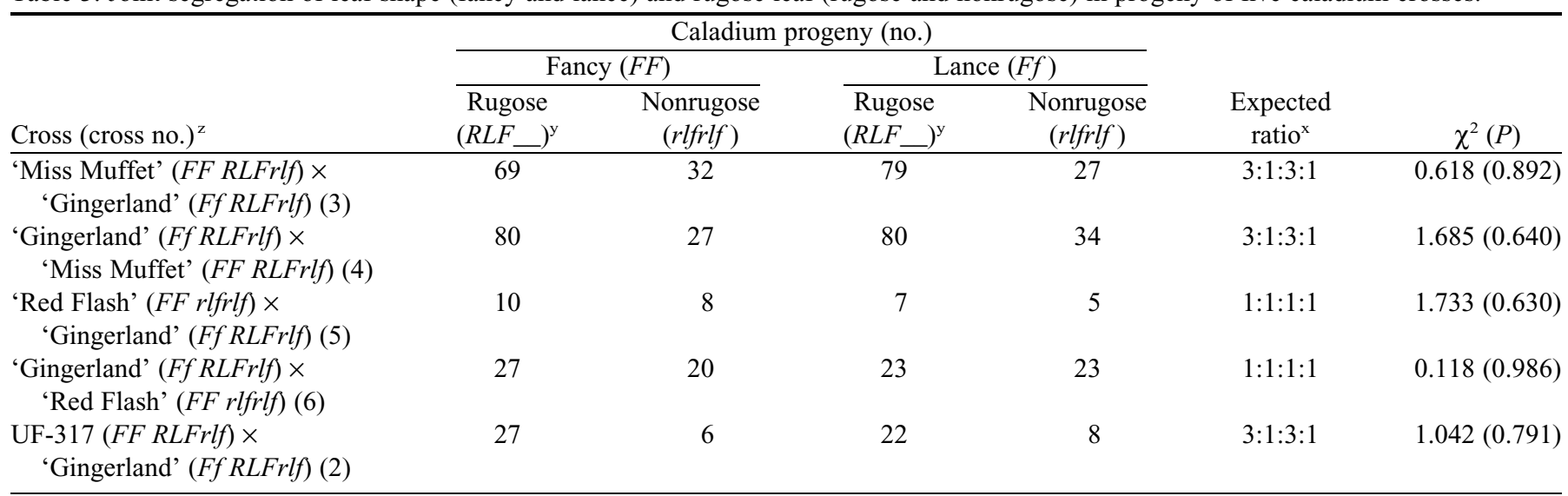

${ }^{\mathrm{z}}$ Inferred genotypes for each parent.

${ }^{\mathrm{y}}$ Two possible genotypes ( $R L F R L F$ or $R L F r l f$, generalized as $R L F_{-}$here) produced rugose progeny, and only recessive genotype ( $\left.r l f r l f\right)$ produced nonrugose (flat) progeny.

${ }^{x}$ Segregation ratio expected for independent inheritance between leaf shape and rugose leaf. 
In this study, progeny of three crosses (UF- $317 \times$ 'Gingerland', 'Miss Muffet' $\times$ 'Gingerland', and 'Gingerland' $\times$ 'Miss Muffet') [Table 3 (cross nos. 2, 3, and 4)] segregated in 3 (fancy, rugose):1 (fancy, nonrugose):3 (lance, rugose): 1 (lance, nonrugose) ( $P=0.640$ to 0.892$)$, as expected for two independently inherited loci. In addition, 1 (fancy, rugose): 1 (fancy, nonrugose):1 (lance, rugose):1 (lance, nonrugose) segregation $(P=0.630$ to 0.986$)$ was observed in progeny of reciprocal crosses between 'Red Flash' and 'Gingerland' [Table 3 (cross nos. 5 and 6)], which also indicated that rugose leaf and leaf shape were under random assortment and were not linked.

GENETIC RELATIONSHIP BETWEEN RUGOSE LEAF AND LEAF SPOTTiNG. Previously, Deng et al. (2008) showed that leaf spotting in 'Gingerland' was controlled by a single locus with two alleles $(S$ and $s$ ) and the nonspotted caladium had a homozygous recessive genotype ss. On the basis of this model, it was expected that the genotype of 'Miss Muffet' and UF-317 for leaf spotting would be $S S$ or Ss. Progeny of selfed 'Miss Muffet' [Table 4 (cross no. 1), $P=0.88$ ] as well as progeny of the cross between 'Miss Muffet' and 'Gingerland' each segregated in 3 (spotted):1 (nonspotted) $(P=0.88)$. Progeny of crosses between 'Miss Muffet' and nonspotted 'Candidum' or 'Aaron' [Table 4 (cross nos. 7, 8, and 14)] showed a segregation ratio of 1 (spotted):1 (nonspotted) $(P=0.25$ to 0.93$)$. These segregation ratios suggested that 'Miss Muffet' was heterozygous at the leaf spotting locus with a genotype of Ss.
When UF-317 was crossed with nonspotted 'Aaron' [Table 4 (cross no. 15)] or 'Florida Moonlight' [Table 4 (cross no. 18)], their progeny showed a 1 (spotted): 1 (nonspotted) segregation ratio $(P=0.53$ to 0.77$)$. When UF-317 was crossed with spotted 'Gingerland' [Table 4 (cross no. 2)], their progeny segregated in 3 (spotted):1 (nonspotted) $(P=0.82)$. These segregation ratios indicated that UF-317 was also heterozygous $(S S)$ at the leaf spotting locus.

Both rugose leaf and leaf spotting segregated in four pseudo $\mathrm{F}_{2}$ and six pseudo $\mathrm{BC}_{1}$ populations (Table 4). Progeny from selfed 'Miss Muffet' [Table 4 (cross no. 1)] deviated from the expected 9 (spotted, rugose):3 (spotted, nonrugose):3 (nonspotted, rugose): 1 (nonspotted, nonrugose) ratio $(P<0.001)$. Segregation ratios also deviated in the progeny of the cross between UF-317 and 'Gingerland' [Table 4 (cross no. 2)] and the reciprocal crosses between 'Gingerland' and 'Miss Muffet' [Table 4 (cross nos. 3 and 4), $P<0.001]$. When 'Miss Muffet' was crossed with 'Candidum' [Table 4 (cross nos. 7 and 8)], their progeny did not segregate in a 1 (spotted, rugose): 1 (spotted, nonrugose):1 (nonspotted, rugose):1 (nonspotted, nonrugose) ratio $(P<0.001)$. Similarly, the progeny of crosses 'Aaron' $\times$ 'Miss Muffet', 'Fairytale Princess' $\times$ 'Miss Muffet', 'Aaron' $\times$ UF-317, and UF-317 × 'Florida Moonlight' [Table 4 (cross nos. 8, 14, 15, 16, and 18)] deviated from an expected 1:1:1:1 ratio $(P<0.001)$ for two loci under random assortment. These results indicated that leaf spotting and rugose leaf were genetically linked.

Table 4. Joint segregation of rugose leaf and leaf spotting in progeny of 10 caladium crosses.

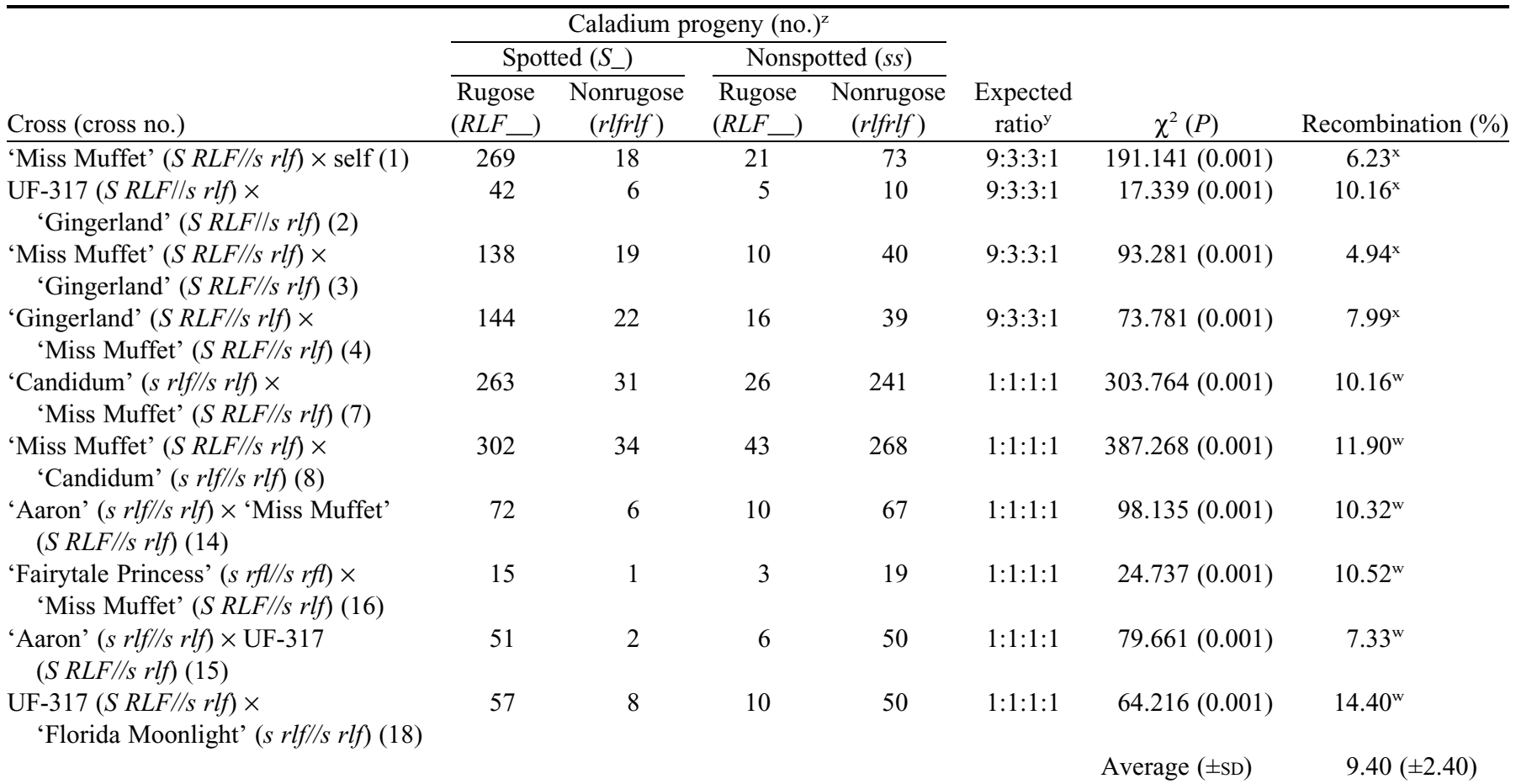

$\overline{{ }^{2}}$ Two possible genotypes ( $R L F R L F$ or $R L F r l f$, generalized as $R L F \_$here) produced rugose progeny, and only recessive genotype $(r l f r l f)$ produced nonrugose (flat) progeny; two possible genotypes ( $S S$ or $S s$, generalized as $S_{-}$) produced spotted progeny, and only the recessive genotype (ss) produced nonspotted progeny.

${ }^{y}$ Segregation ratios expected for independent inheritance between rugose leaf and leaf spotting.

${ }^{x}$ Recombinant frequency in these pseudo $\mathrm{F}_{2}$ populations was calculated as follows: $\{0.5-$ [number of nonspotted and nonrugose progeny $(s \mathrm{r} l f / / \mathrm{s}$ rlf) $\div$ total number of progeny $\left.]^{1 / 2}\right\} \times 100$.

${ }^{w}$ Recombinant frequency in these pseudo $\mathrm{BC}_{1}$ populations was calculated as follows: [number of spotted and nonrugose progeny $(S \mathrm{rlf} / \mathrm{s} \mathrm{rlf})+$ number of nonspotted and rugose progeny $(s R L F / / s \mathrm{rlf})] \div$ total number of progeny $\times 100$. 
In the six pseudo $\mathrm{BC}_{1}$ [Table 4 (cross nos. $7,8,14,15,16$, and 18)], two types of progeny (spotted and rugose, and nonspotted and nonrugose) were observed significantly more abundant than expected for independently inherited traits, suggesting that the rugose leaf allele $(R L F)$ was in a coupling phase with the spotted leaf allele $(S)$ and the nonrugose leaf allele $(r l f)$ was in coupling with the nonspotted leaf allele $(s)$.

The number of double recessive progeny (nonspotted, nonrugose with the genotype of $s \mathrm{rlf} / / \mathrm{s} \mathrm{rlf}$ ) in the four pseudo $\mathrm{F}_{2}$ populations [Table 4 (cross nos. 1, 2, 3, and 4)] and the total number of two types of recombinant progeny (spotted and nonrugose progeny with the genotype of $S \mathrm{rlf} / / \mathrm{s} \mathrm{rlf}$, and nonspotted and rugose progeny with the genotype of $s R L F / / s$ $r l f$ ) in the six pseudo $\mathrm{BC}_{1}$ populations [Table 4 (cross nos. 7,8 , $14,15,16$, and 18)] were used to calculate the percentage of recombination between the leaf spotting locus $S$ and the rugose leaf locus $R L F$. The recombination frequency varied between $4.94 \%$ and $10.16 \%$ in the four pseudo $\mathrm{F}_{2}$ populations and between $7.33 \%$ and $14.40 \%$ in the six pseudo $\mathrm{BC}_{1}$ populations. The average recombination frequency across the 10 crosses was $9.40 \%$, with a SD of $2.40 \%$ (Table 4 ).

GENETIC RELATIONSHIP BETWEEN RUGOSE LEAF AND MAIN VEIN COLOR. Rugose leaf and main vein color segregated in five crosses involving 'Gingerland', 'Miss Muffet', and nonrugose 'Candidum' (Table 5). Previously, it was shown that the main vein color of caladium is controlled by the $V$ locus with three alleles $\left(V^{\mathrm{r}}>V^{\mathrm{w}}>V^{\mathrm{g}}\right)$ for red, white, and green main veins (Deng and Harbaugh, 2006). 'Candidum' and 'Gingerland' were determined to have the genotype of $V^{\mathrm{g}} V^{\mathrm{g}}$ and $V^{\mathrm{w}} V^{\mathrm{g}}$, respectively (Table 1). According to this model, the white-veined 'Miss Muffet' could have either the $V^{\mathrm{w}} V^{\mathrm{w}}$ or $V^{\mathrm{w}} V^{\mathrm{g}}$ genotype. Progeny of the reciprocal crosses between 'Miss Muffet' and 'Candidum' [Table 5 (cross nos.7 and 8)] segregated 1 (white): 1 (green) for the main vein color $(P=0.22$ to 0.48$)$. Progeny of selfed 'Miss Muffet' and reciprocal crosses between 'Miss Muffet' and 'Gingerland' [Table 5 (cross nos. 3 and 4)] segregated in 3 (white): 1 (green) $(P=0.08$ to 0.17 ). These segregation ratios suggested a heterozygous genotype $\left(V^{\mathrm{w}} V^{\mathrm{g}}\right)$ for 'Miss Muffet' at the $V$ locus (Table 1).

When both rugose leaf and main vein color were considered, progeny of selfed 'Miss Muffet' deviated from 9 (white veined, rugose):3 (green veined, rugose):3 (white veined, nonrugose):1 (green veined, nonrugose) $(P<0.001)$, the segregation ratio expected for two independently inherited traits. Progeny of the crosses between 'Miss Muffet' and 'Gingerland' [Table 5 (cross nos. 3 and 4$)$ ] also deviated $(P<0.001)$. When 'Candidum' was crossed reciprocally with 'Miss Muffet' [Table 5 (cross nos. 7 and 8)], progeny did not segregate in 1 (white veined, rugose):1 (green veined, rugose):1 (green veined, nonrugose): 1 (green veined, nonrugose) $(P<0.0001)$. These deviations suggested genetic linkage between the rugose leaf locus and the main vein color locus.

In these populations, there were significantly more progeny with rugose leaf and green veins and those with nonrugose leaf and white veins than expected, suggesting a repulsion phase between the white vein allele $\left(V^{\mathrm{w}}\right)$ and the rugose leaf allele $(R L F)$.

In the three pseudo $F_{2}$ populations (selfed 'Miss Muffet', and the reciprocal crosses between 'Miss Muffet' and 'Gingerland'), progeny with the green veins and nonrugose leaf phenotype resulted from the union of recombinant gametes. On the basis of the frequency of these progeny, the recombination between the rugose leaf locus $R L F$ and the main vein color locus $V$ was estimated to be between $9.51 \%$ and $15.54 \%$ (Table 5). In the two pseudo $\mathrm{BC}_{1}$ populations (reciprocal crosses between 'Candidum' and 'Miss Muffet'), progeny with white veins and rugose leaves and those with green veins and nonrugose leaves resulted from recombination between the main vein color and the rugose leaf loci. In these two populations, the recombination frequency was $10.52 \%$ and $12.67 \%$, respectively. The average recombination frequency between the main vein color locus $V$ and the rugose leaf locus $R L F$ in all five crosses was $11.70 \%$, with a SD of $2.44 \%$ (Table 5 ).

Table 5. Joint segregation of rugose leaf and main vein color in progeny of five caladium crosses.

\begin{tabular}{|c|c|c|c|c|c|c|c|}
\hline \multirow[b]{3}{*}{ Cross (cross no.) } & \multicolumn{4}{|c|}{ Caladium progeny (no.) $)^{z}$} & \multirow[b]{3}{*}{$\begin{array}{l}\text { Expected } \\
\text { ratio }^{y}\end{array}$} & \multirow[b]{3}{*}{$\chi^{2}(P)$} & \multirow[b]{3}{*}{ Recombination (\%) } \\
\hline & \multicolumn{2}{|c|}{ Rugose $\left(R L F_{\ldots}\right)$} & \multicolumn{2}{|c|}{ Nonrugose (rlfrlf) } & & & \\
\hline & $\begin{array}{l}\text { White } \\
\left(V^{\mathrm{w}}\right)\end{array}$ & $\begin{array}{l}\text { Green } \\
\left(V^{\mathrm{g}} V^{\mathrm{g}}\right)\end{array}$ & $\begin{array}{l}\text { White } \\
\left(V^{\mathrm{w}}{ }_{-}\right)\end{array}$ & $\begin{array}{l}\text { Green } \\
\left(V^{\mathrm{g}} V^{\mathrm{g}}\right)\end{array}$ & & & \\
\hline $\begin{array}{l}\text { 'Miss Muffet' }\left(V^{\mathrm{w}} r l f / / V^{\mathrm{g}} R L F\right) \times \\
\text { self (1) }\end{array}$ & 189 & 101 & 87 & 4 & $9: 3: 3: 1$ & $35.098(0.001)$ & $10.25^{\mathrm{x}}$ \\
\hline $\begin{array}{l}\text { 'Miss Muffet' }\left(V^{\mathrm{w}} r l f / / V^{\mathrm{g}} R L F\right) \times \\
\text { 'Gingerland' }\left(V^{\mathrm{w}} r l f / / V^{\mathrm{g}} R L F\right)(3)\end{array}$ & 90 & 58 & 54 & 5 & $9: 3: 3: 1$ & $26.301(0.001)$ & $15.54^{\mathrm{x}}$ \\
\hline $\begin{array}{l}\text { 'Gingerland' }\left(V^{\mathrm{w}} r l f / / V^{\mathrm{g}} R L F\right) \times \\
\text { 'Miss Muffet' }\left(V^{\mathrm{w}} r l f / / V^{\mathrm{g}} R L F\right)(4)\end{array}$ & 98 & 62 & 59 & 2 & $9: 3: 3: 1$ & $33.319(0.001)$ & $9.51^{\mathrm{x}}$ \\
\hline $\begin{array}{l}\text { 'Candidum' }\left(V^{\mathrm{g}} r l f / / V^{g} r l f\right) \times \\
\text { 'Miss Muffet' }\left(V^{w} r l f / / V^{g} R L F\right)(7)\end{array}$ & 28 & 261 & 241 & 31 & $1: 1: 1: 1$ & $553.076(0.001)$ & $10.52^{\mathrm{w}}$ \\
\hline $\begin{array}{l}\text { 'Miss Muffet' }\left(V^{w} r l f / / V^{g} R L F\right) \times \\
\text { 'Candidum' }\left(V^{g} r l f / / V^{g} r l f\right)(8)\end{array}$ & 45 & 300 & 267 & 35 & $1: 1: 1: 1$ & $631.076(0.001)$ & $12.67^{\mathrm{w}}$ \\
\hline & & & & & & Average $( \pm \mathrm{SD})$ & $11.70( \pm 2.44)$ \\
\hline
\end{tabular}

$\overline{{ }^{z}}$ Two possible genotypes ( $R L F R L F$ or $R L F r l f$, generalized as $R L F \_$here) produced rugose progeny, and only recessive genotype $(r l f r l f)$ produced nonrugose (flat) progeny; two possible genotypes ( $V^{\mathrm{w}} V^{\mathrm{w}}$ or $V^{\mathrm{w}} V^{\mathrm{g}}$, generalized as $V^{\mathrm{w}}$ ) produced white-veined progeny, and only the recessive genotype $\left(V^{\mathrm{g}} V^{\mathrm{g}}\right)$ produced green-veined progeny.

${ }^{y}$ Segregation ratios expected for independent inheritance for rugose leaf and main vein color.

${ }^{x}$ Recombinant frequency in these pseudo $\mathrm{F}_{2}$ populations was calculated using the following formula: $\{$ [number of green-veined and nonrugose progeny $\left(V^{\mathrm{g}} \mathrm{rlf} / / V^{\mathrm{g}} \mathrm{rlf}\right) \div$ total number of progeny $\left.]^{1 / 2}\right\} \times 100$.

${ }^{\mathrm{w}}$ Recombinant frequency in these pseudo $\mathrm{BC}_{1}$ populations was calculated using the following formula:(number of rugose and white-veined progeny + number of nonrugose and green-veined progeny) $\div$ total number of progeny $\times 100$. 
GeNetiC DisTANCES AND GENE ORDER AMONG RUGOSE LEAF, LEAF SPOTTING, AND MAIN VEIN COLOR. Progeny of crosses between 'Miss Muffet' and 'Candidum' segregated for rugose leaf, leaf spotting, and main vein color [Table 6 (cross nos. 7 and 8)]. On the basis of the genotype of the two parents determined above, these populations should behave like a pseudo $\mathrm{BC}_{1}$ population, allowing the determination of recombination frequencies among the three traits based on progeny phenotype and ordering of the three loci controlling these traits (Supplemental Fig. 1). The recombination frequency between $S$ and $V, S$ and $R L F$, and $V$ and $R L F$, were $0.41 \%, 11.09 \%$, and $11.50 \%$, respectively (Table 6 ). These recombination frequencies suggest that the leaf spotting locus $S$ would be located between the main vein color locus $V$ and the rugose leaf locus $R L F$ (Fig. 2). Progeny resulting from double crossover among the loci were not observed in the segregating $\mathrm{BC}_{1}$ populations (Table 6). A genetic linkage map consisting of these three loci were constructed based on the recombination frequencies observed in these two pseudo $\mathrm{BC}_{1}$ populations and the Kosambi mapping function (Fig. 2).

\section{Discussion}

Rugose leaves represent a very interesting and valuable character to caladium cultivars. This study was the first effort to understand the mode of inheritance of rugose leaves in this ornamental aroid and in the Araceae family. The information gained here can guide plant breeders in planning crosses for developing new rugose-leaved caladium cultivars. 'Gingerland', 'Miss Muffet', and UF-317 examined in this study, all have a heterozygous genotype at the rugose leaf locus. If these cultivars/breeding lines are crossed with each other, about three-fourths of their progeny are expected to have rugose leaves. When one of them is crossed with a nonrugose cultivar, about half of the progeny is likely to express rugose leaves. Therefore, these rugose cultivars or breeding line could be valuable breeding parents for developing new cultivars with rugose leaves.

The joint segregation analysis suggested that rugose leaf locus $R L F$ is independent from the leaf shape locus $F$, but is closely linked with the leaf spotting locus $S$ and the main vein color locus $V$. Three-point analysis indicated that $S$ is located between $R L F$ and $V$ (Fig. 2). Previously, Deng et al. (2008) reported that the recombination frequency between $S$ and $V$ in crosses between 'Gingerland' and 'Candidum' varied between $0.0 \%$ and $1.1 \%$. In this study, the recombination frequency between $S$ and $V$ in crosses between 'Miss Muffet' and 'Candidum' was $0.41 \%$, which is very close to the recombination value observed in the cross between 'Gingerland' and 'Candidum'.

On the other hand, because of the tight linkage among $V, S$, and $R L F$ loci, very few progeny resulted from the recombination between the $V$ and the $S$ loci, and no progeny resulted from double crossover among the three loci. Should the major breeding objective be to select new combinations of leaf characteristics such as rugose leaf, main vein color, and leaf spotting, a sufficient breeding population size will be required. The newly developed genetic linkage map should offer a valuable tool for estimating the proper breeding population sizes.

Caladium and several other species in the Araceae family seem to share similar modes of inheritance for certain foliar characteristics. For example, the color of the midribs and the leaf variegation pattern in Dieffenbachia are reportedly controlled by dominant nuclear genes $W^{\mathrm{m}}$ and $P v^{1}$, respectively

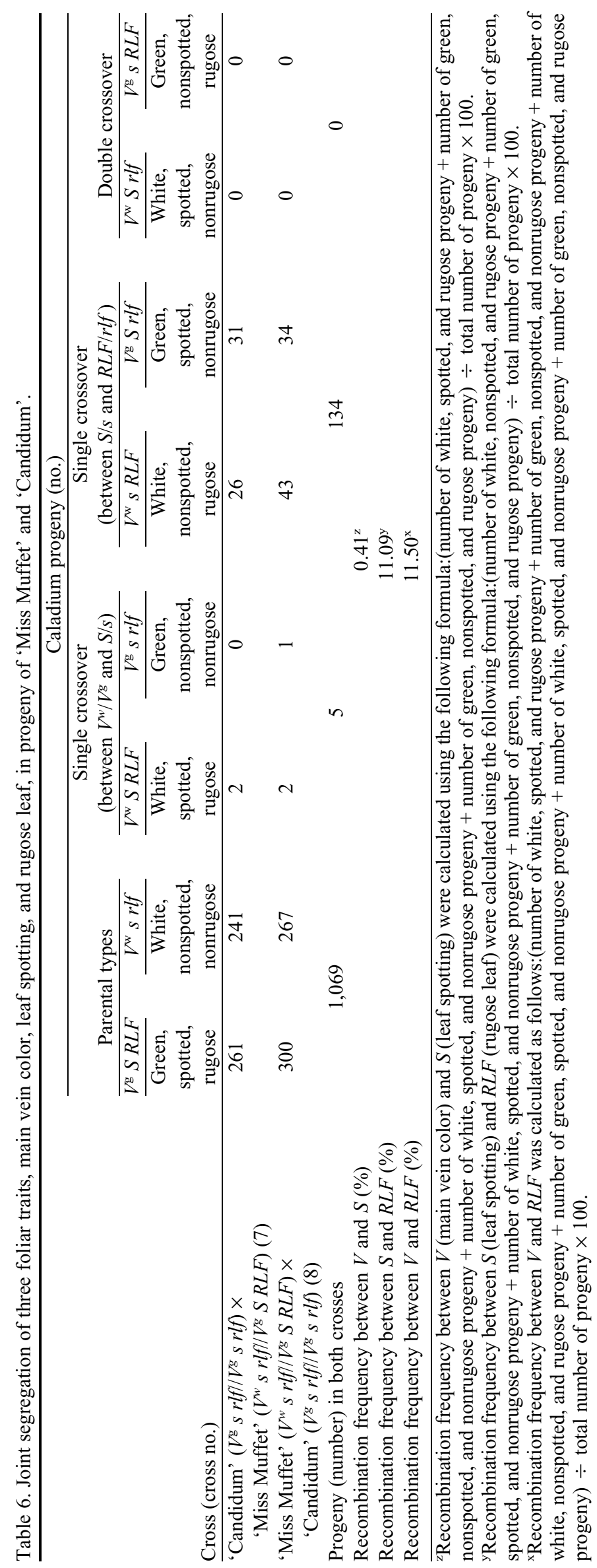




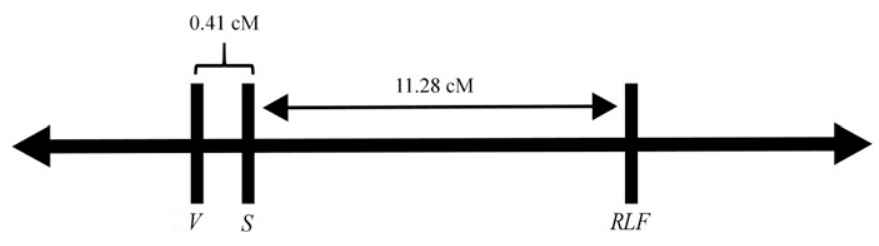

Fig. 2. Genetic linkage map of three loci for main vein color $(V)$, leaf spotting $(S)$, and rugose leaf $(R L F)$. Genetic distances were calculated from the recombination frequencies among $V, S$, and $R L F$ in two pseudo $\mathrm{BC}_{1}$ populations of caladium 'Miss Muffet' $\left(V^{\mathrm{w}} s \mathrm{rlf} / / V^{g} S R L F\right)$ and 'Candidum' $\left(V^{\mathrm{g}} s r l f / / V^{\mathrm{g}} s r l f\right)$ using the Kosambi mapping function.

(Henny, 1982). Similarly, a single dominant nuclear gene controls the foliar variegation pattern in Aglaonema (Henny, 1992). Similar modes of inheritance have been observed for the main vein color, leaf spotting, and blotching in caladium (Deng and Harbaugh, 2006; Deng et al., 2008). Rugose leaves have been observed in several other ornamental aroids, including Epipremnum (Nelson, 2008), but the mode of inheritance for the rugose leaves in those aroids have not been elucidated. Information on the inheritance pattern of rugose leaves gained in this study may be useful for initiating similar studies in Epipremnum and other aroids that express rugose leaves. The inheritance of rugose leaves have been studied in several other plants, including upland cotton, Desmodium, eggplant, and soybean (Chow, 1982; Csillery, 1983; Stephens et al., 1991; Turcotte and Feaster, 1965; Wilcox and Abney, 1991). The mode of inheritance for the rugose leaf in caladium seems to be similar to what was observed in upland cotton, but different from the observed mode of inheritance for the rugose leaf in Desmodium, eggplant, and soybean. Thus, the results from this study may be of value to further our understanding of the mode of inheritance for rugose leaves in these plants. Asano et al. (2004) reported that the aberrant leaf epidermal cell division was the major cause of leaf rugosity in Arabidopsis thaliana. Jiang et al. (2012) conducted a cytological examination of rugose leaves in maize (Zea mays) and found out that irregular leaf epidermal cells resulted in rugose-looking leaves. Reportedly, a number of genes, such as the maize dill gene (an AP2 transcription factor-like gene) and the A. thaliana CRUMPLED $L E A F$ gene (encoding a protein in plastids), are involved in the formation of rugose leaves (Asano et al., 2004; Jiang et al., 2012). These findings can be used to facilitate further studies of caladium rugose leaves at the cellular and molecular levels.

\section{Literature Cited}

Asano, T., Y. Yoshioka, S. Kurei, W. Sakamoto, and Y. Machida. 2004. A mutation of the CRUMPLED LEAF gene that encodes a protein localized in the outer envelope membrane of plastids affects the pattern of cell division, cell differentiation, and plastid division in Arabidopsis. Plant J. 38:449-459.

Bell, M.L., G. Wilfret, and D.A. Devoll. 1998. Survey of caladium tuber producers for acreage of cultivars grown. Proc. Florida State Hort. Soc. 111:32-34.

Chow, K.H. 1982. Inheritance of rugose leaf in Desmodium. Pac. Sci. 36:221-228

Csillery, G. 1983. New capsicum mutants found on seedling, growth type, leaf, flower and fruit. Proc. 5th Eucarpia Meeting of Capsicum and Eggplant Working Group, p. 127-130.

Deng, Z. and B.K. Harbaugh. 2006. Independent inheritance of leaf shape and main vein color in caladium. J. Amer. Soc. Hort. Sci. 131:53-58.

Deng, Z. and B.K. Harbaugh. 2009. Leaf blotching in Caladium (Araceae) is under simple genetic control and tightly linked to vein color. HortScience 44:40-43.

Deng, Z., B.K. Harbaugh, R.K. Schoellhorn, and R.C. Andrew. 2005. 2003 Survey of the Florida Caladium Tuber Production Industry. Univ. Florida/IFAS Ext. Fact Sheet ENH 1007. 16 Mar. 2016. $<$ http://edis.ifas.ufl.edu/EP258 $>$.

Deng, Z., F. Goktepe, and B.K. Harbaugh. 2008. Inheritance of leaf spots and their genetic relationships with leaf shape and vein color in Caladium. J. Amer. Soc. Hort. Sci. 133:78-83.

Gager, C.R. 1991. Leaf spot color and venation pattern inheritance in caladium. PhD Diss., Univ. Florida, Gainesville, FL.

Harbaugh, B.K. and G.J. Wilfret. 1979. Gibberellic acid $\left(\mathrm{GA}_{3}\right)$ stimulates flowering in Caladium hortulanum Birdsey. HortScience 14:72-73.

Henny, R.J. 1982. Inheritance of foliar variegation in two Dieffenbachia cultivars. J. Hered. 73:384.

Henny, R.J. 1992. Inheritance of the foliar variegation pattern from Aglaonema nitidum (Jack) Kunth 'Ernesto's Favorite'. HortScience 27:274.

Jiang, F., M. Guo, F. Yang, K. Duncan, D. Jackson, A. Rafalski, S. Wang, and B. Li. 2012. Mutations in an AP2 transcription factor-like gene affect internode length and leaf shape in maize. PLoS One 7: e37040.

Nelson, S.C. 2008. Dasheen mosaic of edible and ornamental aroids. 2 Mar. 2016. <http://scholarspace.manoa.hawaii.edu/handle/10125/ $12392>$.

Preacher, K.J. 2001. Calculation for the chi-square test: An interactive calculation tool for chi-square tests of goodness of fit and independence. 2 Sept. 2014. <http://www.quantpsy.org/chisq/chisq.htm>.

Stephens, P.A., U. Barwale-Sehr, C.D. Nickell, and J.M. Wildholm. 1991. A cytoplasmatically inherited, wrinkled-leaf mutant in soybean. J. Hered. 82:71-73.

Turcotte, E. and C.V. Feaster. 1965. Inheritance of rugate leaf in pima cotton. J. Hered. 56:234-236.

Wilcox, J.R. and T.S. Abney. 1991. Inheritance of a narrow, rugoseleaf mutant in Glycine max. J. Hered. 82:421-423.

Wilfret, G.J. 1983. Inheritance of vein color in caladium leaves. HortScience 18:610 (abstr.).

Wilfret, G.J. 1993. Caladium, p. 239-247. In: A. de Hertogh and M. le Nard (eds.). The physiology of flower bulbs. Elsevier, New York, NY. 


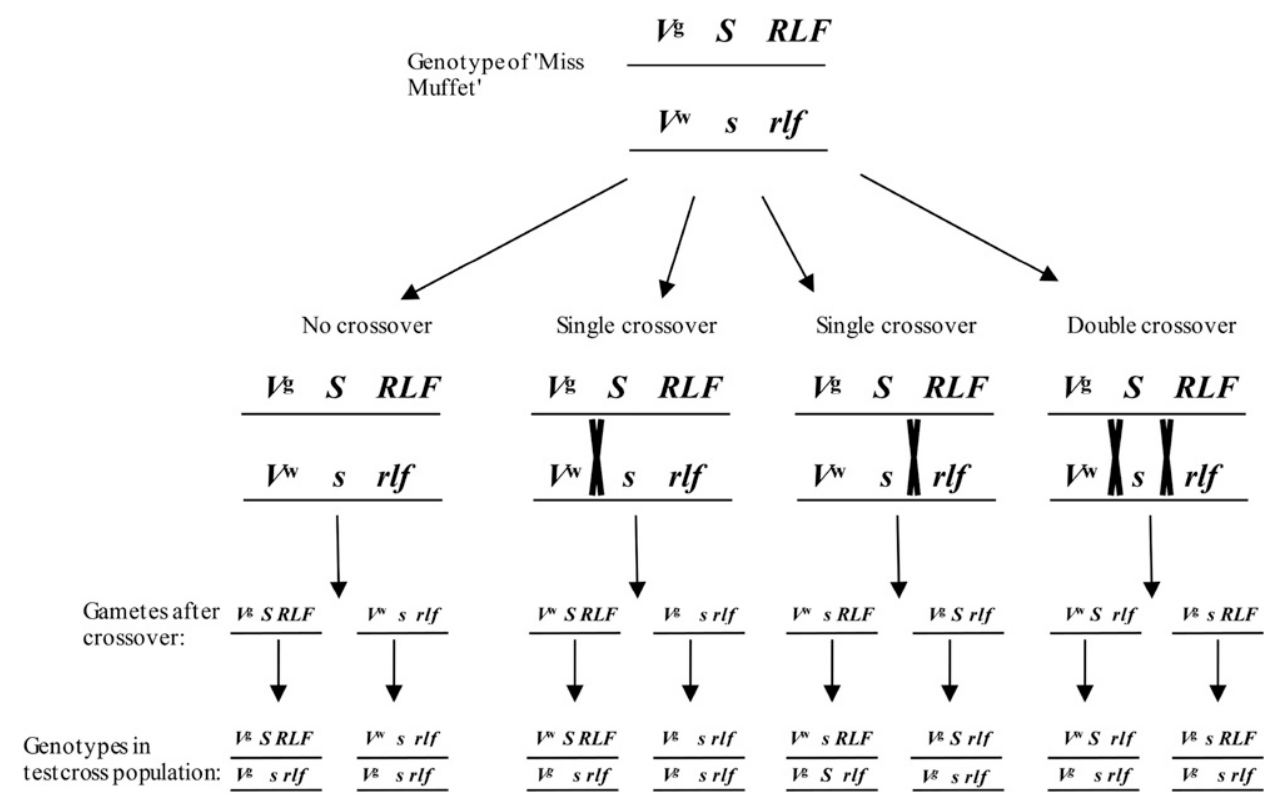

Supplemental Fig. 1. Expected parental and recombinant gametes from caladium 'Miss Muffet', which is heterozygous at the $V, S$, and $R L F$ loci, and expected genotypes in test cross populations. 